\title{
Ash transformations in pulverised fuel co- combustion of straw and woody biomass
}

\author{
Daniel Nordgren ${ }^{1,2 \star}$, Henry Hedman ${ }^{3}$, Nader Padban $^{4}$, Dan Boström ${ }^{5}$, Marcus Öhman ${ }^{2}$ \\ ${ }^{1}$ Innventia $\mathrm{AB}$ \\ Drottning Kristinas väg 63, PO Box 5604 \\ 11486 Stockholm \\ Sweden \\ Phone: +46 (0)8 6767291 \\ Fax: +46 (0)8 4115518 \\ daniel.nordgren@innventia.com \\ * corresponding author \\ ${ }^{2}$ Luleå University of Technology \\ Division of Energy Engineering \\ 97187 Luleå \\ Sweden \\ marcus.ohman@ltu.se \\ ${ }^{3}$ Energy Technology Centre \\ PO Box 726 \\ SE-941 28 Piteå \\ Sweden \\ henry@etcpitea.se \\ ${ }^{4}$ Vattenfall Research and Development AB \\ Jämtlandsgatan 99 \\ 16287 Stockholm \\ Sweden \\ nader.padban@vattenfall.com \\ ${ }^{5}$ Umeå University \\ Energy Technology and Thermal Process Chemistry, \\ 90781 Umeå \\ Sweden \\ dan.bostrom@chem.umu.se
}




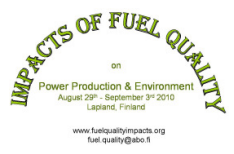

\section{ABSTRACT}

Ash transformation processes have been studied during co-firing of wheat straw and pine stem wood and softwood bark. Pilot-scale trials in a $150 \mathrm{~kW}$ pulverised-fuel-fired burner were performed. Thermodynamic equilibrium calculations were made to support the interpretation of the results. The results show that fast reactions involving gaseous ash compounds are favored at the expense of reactions where condensed components participate. Accordingly, the conditions promote gas phase reactions resulting in the formation of chlorides, sulfate and carbonates whereas reactions involving condensed reactants are suppressed. Both the slagging and fouling propensity of all co-firing mixes was reduced compared to that for pure straw. For the wood/straw mixes this was mainly due to a dilution of the ash forming elements of straw whereas for straw/bark, an additional effect from interaction between the fuel ash components was observed to primarily reduce slagging. In general it can be concluded that under powder combustion conditions equilibrium are approached selectively and that the ash matter are strongly fractionated. The general results in this paper are useful for straw-fired power stations looking for alternative co-firing fuels.

Keywords: co-combustion, pulverised fuel combustion, straw, wood, bark, biomass, deposit formation, slagging, fouling, alkali, ash transformation

\section{INTRODUCTION}

The use of straw in conventional boilers is a great technical challenge, especially when it comes to dealing with problems from slagging and fouling [1-3]. The ash related operational problems with biomass in general, and straw in particular, can be reduced by co-firing with coal, primarily due to "positive" interactions between clay minerals and/or sulphur in coal and alkali in biomass [4]. Full-scale experiences from pulverised fuelfired boilers have shown that $10-20 \%$ straw (energy) can be co-fired with coal without any major operational problems [5]. As the demand for $\mathrm{CO}_{2}$ neutral energy resources will continue to increase, other fuels (and/or additives) than coal need to be considered for cofiring with straw. Several investigators have shown positive effects on fouling by cofiring of straw and peat [6] and by using additives such as sand and bentonite [7]. Other findings indicate that slagging, when firing pure woody fuels, can be decreased by addition of limestone [8].

Biomass has traditionally been fired in grate or fluidized bed boilers and suspension firing of biomass is still considered as a fairly new technology, and hence, limited investigations have been published on large-scale firing/co-firing of pure biomass fuels in pulverised fuel-fired boilers $[9,10]$. The objectives of the present work were therefore to study general ash transformation processes, including slagging and fouling, when straw and woody (Ca-rich) biomass, stem wood and bark, are co-fired in a pilot-scale pulverised fuel-fired burner. To facilitate the interpretations of the findings chemical equilibrium calculation were performed on selected fuel mixes. 


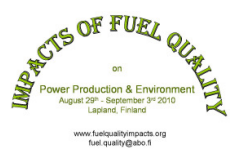

\section{MATERIALS AND METHODS}

\subsection{Fuels}

A typical wheat straw pellet from Denmark along with two Swedish forest (woody) fuels, comprising pine stem wood pellets and softwood bark pellets, were selected as cofiring fuels in this study. Ultimate analysis and concentrations of the main ash forming elements of the fuels are given in Table 1. The straw has relatively high concentrations of $\mathrm{Si}$ and $\mathrm{K}$. The softwood bark is relatively rich in both $\mathrm{Ca}$ and $\mathrm{Si}$, whereas the pine stem wood pellet is relatively low in all of the main ash forming elements. Out of these fuels, a total of 5 different fuel mixtures were produced (by mixing): (i) pure straw, (ii) straw/bark 50/50, (iii) straw/bark 75/25, (iv) straw/wood 75/25 and (v) straw/wood 50/50 (wt-\%). Prior to combustion, the fuels were milled into similar particle size distributions $(100 \%<1 \mathrm{~mm}, 75 \%<0.5 \mathrm{~mm}$ and $30 \%<0.25 \mathrm{~mm})$.

Table 1. Fuel characteristics (units for inorganic elements in wt-\% DS)

\begin{tabular}{lllll|llll}
\hline & Straw & Bark & Wood & Unit & & Straw & Bark & Wood \\
\hline Moist. & 7.9 & 9.6 & 7 & wt-\% & Si & 0.823 & 0.396 & 0.012 \\
Ash & 4.8 & 3.7 & 0.3 & wt-\% DS & $\mathrm{Al}$ & 0.005 & 0.048 & 0.001 \\
$\mathrm{C}$ & 47.2 & 52.5 & 50.9 & wt-\% DS & $\mathrm{Ca}$ & 0.365 & 0.851 & 0.068 \\
$\mathrm{H}$ & 5.8 & 5.7 & 6.2 & wt-\% DS & $\mathrm{Fe}$ & 0.003 & 0.022 & 0.001 \\
$\mathrm{O}$ & 46.5 & 41.7 & 42.9 & wt-\% DS & $\mathrm{K}$ & 0.548 & $0 . .102$ & $0 . .017$ \\
$\mathrm{~N}$ & 0.8 & 0.4 & 0.08 & wt-\% DS & $\mathrm{Mg}$ & 0.082 & 0.074 & 0.009 \\
$\mathrm{Cl}$ & 0.42 & 0.02 & 0.01 & wt-\% DS & $\mathrm{Mn}$ & 0.003 & 0.048 & 0.007 \\
S & 0.13 & 0.05 & $<0.01$ & wt-\% DS & $\mathrm{Na}$ & 0.022 & 0.019 & 0.001 \\
LHV & 17.3 & 18 & 19.2 & MJ/kg DS & & & & \\
\hline
\end{tabular}

\subsection{Experimental facility, test procedure and operating conditions}

Combustion of the fuel mixtures was conducted in a $150 \mathrm{~kW}$ VTS swirl powder burner. Average thermal input was $100 \mathrm{~kW}$ and $3-4$ vol- $\%_{\mathrm{dg}}$ excess $\mathrm{O}_{2}$ in the flue gas, except for the 50/50 straw/bark fuel which had an average excess $\mathrm{O}_{2}$ of 6.5 vol- $\%_{\mathrm{dg}}$. The flue gas $\mathrm{CO}$ concentration for all fuels was below $120 \mathrm{mg} / \mathrm{Nm}^{3}$ at 6 vol- $\%_{\mathrm{dg}}$. The combustion air was distributed as $9 \%$ transport air, $17 \%$ primary air, $34 \%$ secondary air and $40 \%$ tertiary air during all trials. The average mean particle residence time in the furnace is about 3 seconds and the duration of each trial was between 5-6 hours.

During the experiments, sampling of bottom ash was made at position "1" when the temperature of the ceramic brick wall was $1000^{\circ} \mathrm{C}$, Figure 1. Air-cooled deposition probes with test rings of stainless steel, simulating superheater/heat exchanger tube surfaces at $550^{\circ} \mathrm{C}$ and $250^{\circ} \mathrm{C}$, was used to collect deposits in the convective pass of the boiler at position " 2 and 3" ( 2 hour exposure time) at flue gas temperatures of $800^{\circ} \mathrm{C}$ and $500^{\circ} \mathrm{C}$ respectively. After the experiments was finalised, the furnace was allowed to cool down before fly ash was collected further down the flue gas channel at position "4". Total particle mass (PMtot) concentrations were measured through iso-kinetic sampling from the flue gas, at position " 5 " where the flue gas temperature was $150^{\circ} \mathrm{C}$, using conventional equipment with quartz filters. The PM mass size distribution was determined in a 13-stage low-pressure cascade impactor (LPI) from Dekati Ltd, which separates particles according to their aerodynamic diameter in the interval of 0.03-10 $\mu \mathrm{m}$. 


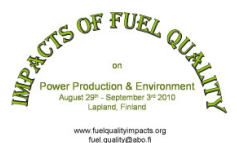

Aluminum foils (not greased) were used as substrates in the impactor and the impactor was heated to around $150^{\circ} \mathrm{C}$ during the sampling. During the experiments $\mathrm{O}_{2}, \mathrm{CO}, \mathrm{NO}$, $\mathrm{HCl}$ and $\mathrm{SO}_{2}$ were continuously measured by an FT-IR analyzer. The average flue gas temperatures, measured by thermocouples at positions T1-T4, was between $1100-1200^{\circ} \mathrm{C}$ during the sampling period.

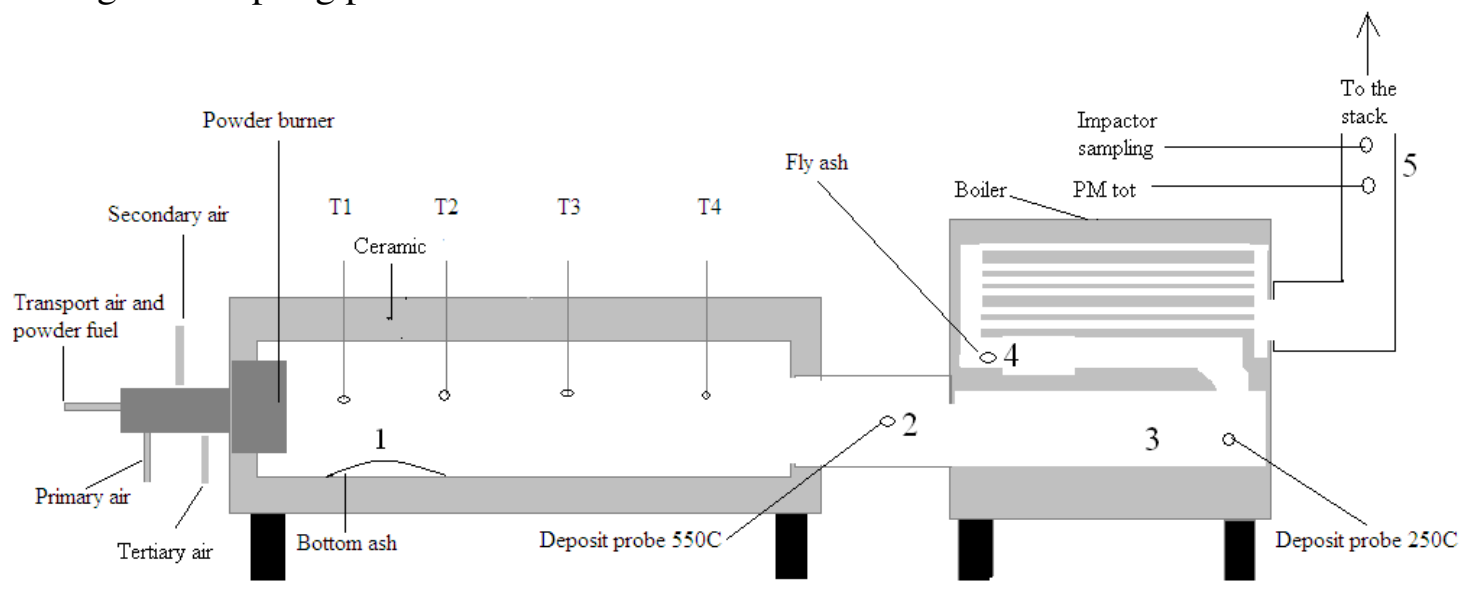

Figure 1. Schematic view of the burner, furnace, boiler and measurement positions.

\subsection{Chemical and visual analysis of ash, particles and deposits}

After the combustion experiments the following ashes/deposits were characterized with analysis methods described below: (i) bottom ash/slag, (ii) deposited ash on the cooled probes, (iii) particulate matter on selected impactor plates and (iv) fly ash. Morphologies and elemental composition were analysed by a Philips XL30 environmental scanning electron microscope (ESEM) equipped with energy dispersive X-ray spectroscopy (EDS) detector. Each fraction was analysed by four area analysis. Identification of crystalline phases was made by X-ray powder diffraction (XRD) using a commercial software from Bruker and PDF2 database. Impactor plates 2-4, 6-8 and 9-11, with mean geometric mean diameters (GMD) of $0.06-0.19,0.5-1.34$ and $2.12-5.54 \mu \mathrm{m}$ respectively, were analysed by SEM/EDS. Impactor plates 3-5 (GMD of 0.09-0.24 $\mu \mathrm{m}$ ) was also analysed by XRD. In addition, visual inspection/classification of bottom ash/slag was made according to the procedure described by Öhman [8]. The classification scheme can also be seen as an indication of the amount amorphous material in the bottom ash.

\subsection{Chemical equilibrium model calculations}

Global chemical equilibrium model calculations were performed using the software program FactSage 6.1. The program uses the method of minimization of the total Gibbs free energy of the system. Thermodynamic data were taken from the FactSage database, including all available stoichiometric data as well as the appropriate data and models for non-ideal solid and liquid solutions and the calculations were made at ambient pressure (1 bar) and an air-to-fuel (mass) ratio of 1.2 covering a temperature range of $900-1200^{\circ} \mathrm{C}$. The following elements were used: $\mathrm{C}, \mathrm{O}, \mathrm{H}, \mathrm{N}, \mathrm{S}, \mathrm{Cl}, \mathrm{P}, \mathrm{K}, \mathrm{Na}, \mathrm{Si}, \mathrm{Ca}, \mathrm{Al}, \mathrm{Fe}, \mathrm{Mg}, \mathrm{Mn}$, and the number of phases and solution phases were 227 and 7 respectively, all solution models used in the calculations are shown in Table 2. 


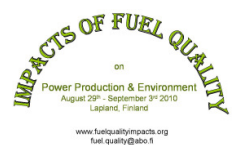

Table 2. Solution models used in the chemical equilibrium model calculations using FactSage 6.1.

$\begin{array}{ll}\begin{array}{l}\text { Solution models: } \\ \text { Base phase }\end{array} & \text { Full name } \\ \text { FToxid SLAGB } & \text { BSlag-liq } \\ \text { FTpulp MELTA } & \text { ASalt-liq } \\ \text { FTsalt-LCSO } & \text { liq-K, } \mathrm{Ca} / \mathrm{CO}_{3}, \mathrm{SO}_{4} \\ \text { FTsalt-LSUL } & \text { liq-Ca, } \mathrm{Mg}, \mathrm{Na} / / \mathrm{SO}_{4} \\ \text { FTsalt-SCMO } & \mathrm{MgSO} 4-\mathrm{CaSO}_{4}(\mathrm{ss}) \\ \text { FTsalt-SCSO } & \mathrm{K},[\mathrm{Ca}] / \mathrm{CO}_{3}, \mathrm{SO}_{4}(\mathrm{ss}) \\ \text { FTsalt-SSUL } & \mathrm{Na}[\mathrm{Mg}, \mathrm{Ca}] / / \mathrm{SO}_{4}\end{array}$

\section{RESULTS AND DISCUSSION}

\subsection{Equilibrium model calculations}

The modelling result on the speciation of the main ash forming elements in the fuel mixes is given in Table 3, at two global system temperatures of $1000^{\circ} \mathrm{C}$ and $1200^{\circ} \mathrm{C}$. The speciation is expressed as mole- $\%$ of the total amount of moles of each element in the system. It should be clear the applicability of a global equilibrium model to practical combustors has several limitations. The model assumes long (infinite) residence times as well as perfect mixing between all species. Particularly in pulverised fuel-fired systems, with residence times in the order of seconds and with limited mixing of fuel and oxidiser, these limitations need to be taken into consideration when translating the results from the model to practical combustors. Out of all (24) phases found in the XRD analysis, Table 4, eight was present as condensed phases in the equilibrium calculations.

Table 3. Predicted distribution ${ }^{*}$ as mole-\% of in-going elements of $\mathrm{Si}, \mathrm{Ca}, \mathrm{Mg}, \mathrm{K}, \mathrm{S}$ and $\mathrm{Cl}$ at $1000^{\circ} \mathrm{C}$ and $1200^{\circ} \mathrm{C}$.

\begin{tabular}{|c|c|c|c|c|c|c|c|}
\hline $\begin{array}{l}\text { Fuel } \\
\text { mix }\end{array}$ & $\begin{array}{c}\mathrm{T} \\
\left({ }^{\circ} \mathrm{C}\right) \\
\end{array}$ & $\begin{array}{c}\mathrm{Si} \\
(\% \text { of total Si) }\end{array}$ & $\begin{array}{c}\mathrm{Ca} \\
(\% \text { of total Ca) } \\
\end{array}$ & $\begin{array}{c}\mathrm{Mg} \\
\text { (\% of total } \mathrm{Mg} \text { ) }\end{array}$ & $\begin{array}{c}\mathrm{K} \\
(\% \text { of total K) } \\
\end{array}$ & $\begin{array}{c}\mathrm{S} \\
(\% \text { of total } \mathrm{S})\end{array}$ & $\begin{array}{c}\mathrm{Cl} \\
(\% \text { of total } \mathrm{Cl}) \\
\end{array}$ \\
\hline \multirow{2}{*}{ 离 } & 1200 & $\begin{array}{l}21 \% \text { as } \mathrm{CaMgSi} 2 \mathrm{O} 6 \text { (s) } \\
12 \% \text { as } \mathrm{CaSiO} \text { (s) } \\
65 \% \text { as } \mathrm{SiO} 2 \text { (liq) }\end{array}$ & $\begin{array}{l}40 \% \text { as } \mathrm{CaSiO} 3 \text { (s) } \\
35 \% \text { as } \mathrm{CaMgSi} 2 \mathrm{O} 6 \text { (s) } \\
18 \% \text { as } \mathrm{Ca} 3(\mathrm{PO} 4) 2 \text { (s) } \\
7 \% \text { as } \mathrm{CaO} \text { (liq) }\end{array}$ & $\begin{array}{l}95 \% \text { as CaMgSi2O6 (s) } \\
5 \% \text { as MgO (liq) }\end{array}$ & $\begin{array}{l}50 \% \text { as } \mathrm{KCl}(\mathrm{g}) \\
2 \% \text { as } \mathrm{KOH}(\mathrm{g}) \\
48 \% \text { as } \mathrm{K} 2 \mathrm{O}(\mathrm{liq})\end{array}$ & $\begin{array}{l}99 \% \text { as SO } 2(\mathrm{~g}) \\
1 \% \text { as SO3 }(\mathrm{g})\end{array}$ & $\begin{array}{l}76 \% \text { as } \mathrm{KCl}(\mathrm{g}) \\
20 \% \text { as } \mathrm{HCl}(\mathrm{g}) \\
4 \% \text { as } \mathrm{NaCl}(\mathrm{g})\end{array}$ \\
\hline & 1000 & $\begin{array}{l}23 \% \text { as } \mathrm{CaMgSi} 2 \mathrm{O} 6 \text { (s) } \\
13 \% \text { as } \mathrm{CaSiO} 3(\mathrm{~s}) \\
63 \% \text { as } \mathrm{SiO} 2 \text { (liq) }\end{array}$ & $\begin{array}{l}43 \% \text { as } \mathrm{CaSiO} 3(\mathrm{~s}) \\
37 \% \text { as } \mathrm{CaMgSi} 2 \mathrm{O} 6(\mathrm{~s}) \\
6 \% \text { as } \mathrm{Ca} 3(\mathrm{PO}) 4(\mathrm{~s})\end{array}$ & $100 \%$ as CaMgSi2O6 (s) & $\begin{array}{l}42 \% \text { as } \mathrm{KCl} \text { (g) } \\
57 \% \text { as } \mathrm{K} 2 \mathrm{O} \text { (liq) }\end{array}$ & $\begin{array}{l}95 \% \text { as } \mathrm{SO} 2(\mathrm{~g}) \\
2 \% \text { as } \mathrm{SO} 3(\mathrm{~g}) \\
2 \% \text { as } \mathrm{K} 2 \mathrm{SO} 4 \text { (liq) } \\
0.5 \% \text { as } \mathrm{K} 2 \mathrm{SO} 4(\mathrm{~g})\end{array}$ & $\begin{array}{l}63 \% \text { as } \mathrm{KCl}(\mathrm{g}) \\
33 \% \text { as } \mathrm{HCl}(\mathrm{g}) \\
3 \% \text { as } \mathrm{NaCl}(\mathrm{g})\end{array}$ \\
\hline \multirow{2}{*}{ 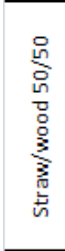 } & 1200 & $\begin{array}{l}23 \% \text { as } \mathrm{CaMgSi} 2 \mathrm{O} 6(\mathrm{~s}) \\
17 \% \text { as } \mathrm{CaSiO} \text { (s) } \\
60 \% \text { as } \mathrm{SiO} 2 \text { (liq) }\end{array}$ & \begin{tabular}{|l}
$47 \%$ as $\mathrm{CaSiO} 3$ (s) \\
$30 \%$ as $\mathrm{CaMgSi} 2 \mathrm{O} 6$ (s) \\
$14 \%$ as $\mathrm{Ca} 3(\mathrm{PO} 4) 2$ (s) \\
$8 \%$ as $\mathrm{CaO}$ (liq)
\end{tabular} & $\begin{array}{l}92 \% \text { as CaMgSi } 206 \text { (s) } \\
8 \% \text { as MgO (liq) }\end{array}$ & $\begin{array}{l}52 \% \text { as } \mathrm{KCl}(\mathrm{g}) \\
5 \% \text { as } \mathrm{KOH}(\mathrm{g}) \\
43 \% \text { as } \mathrm{K} 2 \mathrm{O}(\mathrm{liq})\end{array}$ & $\begin{array}{l}99 \% \text { as SO2 }(\mathrm{g}) \\
1 \% \mathrm{SO} 3(\mathrm{~g})\end{array}$ & $\begin{array}{l}79 \% \text { as } \mathrm{KCl}(\mathrm{g}) \\
17 \% \text { as } \mathrm{HCl}(\mathrm{g}) \\
3 \% \text { as } \mathrm{NaCl}(\mathrm{g})\end{array}$ \\
\hline & 1000 & $\begin{array}{l}25 \% \text { as } \mathrm{CaMgSi} 2 \mathrm{O} 6 \text { (s) } \\
20 \% \text { as } \mathrm{CaSiO} \text { (s) } \\
55 \% \text { as } \mathrm{SiO} 2 \text { (liq) }\end{array}$ & $\begin{array}{l}52 \% \text { as } \mathrm{CaSiO} 3(\mathrm{~s}) \\
33 \% \text { as } \mathrm{CaMgSi} 2 \mathrm{O} 6(\mathrm{~s}) \\
14 \% \text { as } \mathrm{Ca} 3(\mathrm{PO} 4) 2(\mathrm{~s})\end{array}$ & $100 \%$ as CaMgSi2O6 (s) & $\begin{array}{l}45 \% \text { as } \mathrm{KCl} \text { (g) } \\
53 \% \text { as } \mathrm{K} 2 \mathrm{O} \text { (liq) }\end{array}$ & \begin{tabular}{|l}
$95 \%$ as $\mathrm{SO} 2(\mathrm{~g})$ \\
$2 \%$ as $\mathrm{SO} 3(\mathrm{~g})$ \\
$2 \%$ as $\mathrm{K} 2 \mathrm{SO} 4(\mathrm{liq})$ \\
$1 \%$ as $\mathrm{K} 2 \mathrm{SO} 4(\mathrm{~g})$
\end{tabular} & $\begin{array}{l}69 \% \text { as } \mathrm{KCl}(\mathrm{g}) \\
27 \% \text { as } \mathrm{HCl}(\mathrm{g}) \\
4 \% \text { as } \mathrm{NaCl}(\mathrm{g})\end{array}$ \\
\hline \multirow{2}{*}{ 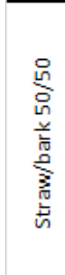 } & 1200 & $\begin{array}{l}25 \% \text { as } \mathrm{CaSiO} 3(\mathrm{~s}) \\
28 \% \text { as } \mathrm{Ca} 2 \mathrm{MgSi} 2 \mathrm{O} 7(\mathrm{~s}) \\
46 \% \text { as } \mathrm{SiO} 2 \text { (liq) }\end{array}$ & $\begin{array}{l}35 \% \text { as } \mathrm{CaSiO} 3(\mathrm{~s}) \\
39 \% \text { as } \mathrm{Ca} 2 \mathrm{MgSi} 2 \mathrm{O} 7(\mathrm{~s}) \\
12 \% \text { as } \mathrm{Ca} 3(\mathrm{PO} 4) 2(\mathrm{~s}) \\
13 \% \text { as } \mathrm{CaO}(\mathrm{liq})\end{array}$ & $\begin{array}{l}93 \% \text { as } \mathrm{Ca} 2 \mathrm{MgSi} 2 \mathrm{O} \text { (s) } \\
7 \% \text { as MgO (liq) }\end{array}$ & $\begin{array}{l}40 \% \text { as } \mathrm{KCl}(\mathrm{g}) \\
7 \% \text { as } \mathrm{KOH}(\mathrm{g}) \\
57 \% \text { as } \mathrm{K} 2 \mathrm{O}(\mathrm{liq})\end{array}$ & $\begin{array}{l}99 \% \text { as } \mathrm{SO} 2(\mathrm{~g}) \\
0.5 \% \mathrm{SO} 3(\mathrm{~g}) \\
0.5 \% \mathrm{~K} 2 \mathrm{SO} 4(\mathrm{~g})\end{array}$ & $\begin{array}{l}87 \% \text { as } \mathrm{KCl}(\mathrm{g}) \\
9 \% \text { as } \mathrm{HCl}(\mathrm{g}) \\
4 \% \text { as } \mathrm{NaCl}(\mathrm{g})\end{array}$ \\
\hline & 1000 & $\begin{array}{l}27 \% \text { as } \mathrm{CaSiO} 3(\mathrm{~s}) \\
30 \% \text { as } \mathrm{Ca} 2 \mathrm{MgSi} 2 \mathrm{O} 7(\mathrm{~s}) \\
41 \% \text { as } \mathrm{SiO} 2 \text { (liq) }\end{array}$ & $\begin{array}{l}38 \% \text { as } \mathrm{CaSiO} 3(\mathrm{~s}) \\
42 \% \text { as } \mathrm{Ca} 2 \mathrm{MgSi} 2 \mathrm{O} 7(\mathrm{~s}) \\
13 \% \text { as } \mathrm{Ca} 5(\mathrm{PO} 4) 3(\mathrm{OH})(\mathrm{s})\end{array}$ & $100 \%$ as $\mathrm{Ca} 2 \mathrm{MgSi} 2 \mathrm{O}$ (s) & $\begin{array}{l}35 \% \text { as } \mathrm{KCl} \text { (g) } \\
64 \% \text { as } \mathrm{K} 2 \mathrm{O} \text { (liq) }\end{array}$ & \begin{tabular}{|l|}
$80 \%$ as $\mathrm{SO} 2(\mathrm{~g})$ \\
$15 \%$ as $\mathrm{K} 2 / \mathrm{Na} 2 /$ \\
$\mathrm{Mg} / \mathrm{CaSO} 4(\mathrm{liq})$ \\
$2 \% \mathrm{SO} 3(\mathrm{~g})$ \\
$1.5 \% \mathrm{~K} 2 \mathrm{SO} 4(\mathrm{~g})$
\end{tabular} & $\begin{array}{l}76 \% \text { as } \mathrm{KCl}(\mathrm{g}) \\
20 \% \text { as } \mathrm{HCl}(\mathrm{g}) \\
3 \% \text { as } \mathrm{NaCl}(\mathrm{g})\end{array}$ \\
\hline
\end{tabular}

*The term "liq" means slag/silicate melt (BSlag-liq). Minor phases have been omitted, thus, sum is not always $100 \%$.

In the case of $\mathrm{Si}$, the addition of both wood and bark to the fuel mixtures reduced the share of Si in the slag (BSlag-liq). Thus, the share of $\mathrm{Si}$ and also $\mathrm{Ca}$ in solid phases increased as more woody biomass was co-fired with straw, and in the case of straw/wood 


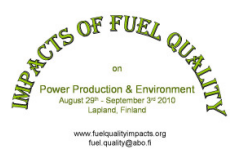

50/50 mix, $\mathrm{Si}$ and $\mathrm{Ca}$ was mainly present as $\mathrm{CaMgSi}_{2} \mathrm{O}_{6}$ (diopside) and $\mathrm{CaSiO}_{3}$ (wollastonite). In the straw/bark 50/50 mix, the solid $\mathrm{Si}$ and $\mathrm{Ca}$ containing phases were mainly $\mathrm{Ca}_{2} \mathrm{MgSi}_{2} \mathrm{O}_{7}$ (akermanite) and $\mathrm{CaSiO}_{3}$ (wollastonite). It is also clear that the share of $\mathrm{Ca}$ in the slag seem to increase as more woody biomass is co-fired with straw, ranging from $7 \%$ for pure straw up to $13 \%$ for the straw/bark $50 / 50$ mix at $1200^{\circ} \mathrm{C} . \mathrm{Mg}$ was mainly found as solid phase $\mathrm{CaMgSiO}_{6}$ (diopside), $\mathrm{Ca}_{2} \mathrm{MgSiO}_{7}$ (akermanite) $\mathrm{Ca}_{3} \mathrm{MgSi}_{2} \mathrm{O}_{8}$ (merwinite) and $\mathrm{Mg}_{2} \mathrm{SiO}_{4}$ (forsterite) as well as smaller amounts in the slag. The share of $\mathrm{Ca}$ and $\mathrm{Mg}$ in the slag increase with both temperature and co-firing rate of woody biomass.

In all straw-bark-wood mixes, $\mathrm{K}$ was mainly found in gas phase and in the slag. The share of $\mathrm{K}$ released to the gas phase at $1200^{\circ} \mathrm{C}$, as the sum of $\mathrm{KCl}(\mathrm{g}), \mathrm{KOH}(\mathrm{g})$ and $\mathrm{K}_{2} \mathrm{SO}_{4}(\mathrm{~g})$, was $52 \%$ for pure straw, $57 \%$ for straw/wood $50 / 50$ and $47 \%$ for straw/bark $50 / 50$. It is clear that the fraction of $\mathrm{K}$ going to gas phase increase with temperature, and the same trend is also observed for sulphur, although sulphur is chiefly present as $\mathrm{SO}_{2}(\mathrm{~g})$. In the case of the straw/bark fuel mix at $1000^{\circ} \mathrm{C}, 15 \%$ of $\mathrm{S}$ is also found in the slag. Chlorine is mainly present as gaseous $\mathrm{KCl}$ and $\mathrm{HCl}$

\subsection{Gaseous emissions of $\mathrm{SO}_{2}, \mathrm{HCl}$ and particle emissions}

The $\mathrm{SO}_{2}$ emissions were highest for pure straw, $155 \mathrm{mg} / \mathrm{Nm}_{\mathrm{dg}}^{3}$ at 6 vol- $\% \mathrm{O}_{2}$, and as the straw share decreased so did the $\mathrm{SO}_{2}$ flue gas emissions for all fuel mixes. The $\mathrm{S}$ release to gas phase, as $\mathrm{SO}_{2}$, were measured and calculated to $44 \%$ for straw, $17-30 \%$ for the straw/wood mixes and $11-22 \%$ for the straw/bark mixes. These are relatively low values compared to the results from the equilibrium modelling calculations at $1200^{\circ} \mathrm{C}$ which showed that between $80-99 \%$ of all $\mathrm{S}$ is present as $\mathrm{SO}_{2}(\mathrm{~g})$, see Table 3. The highest $\mathrm{HCl}$ emissions were observed for pure straw and the two straw/wood mixes at levels between $25-30 \mathrm{mg} / \mathrm{Nm}_{\mathrm{dg}}^{3}$ at 6 vol- $\% \mathrm{O}_{2}$, whereas the levels for straw/bark were between $2-17 \mathrm{mg} / \mathrm{Nm}^{3}{ }_{\mathrm{dg}}$ at 6 vol- $\% \mathrm{O}_{2}$.

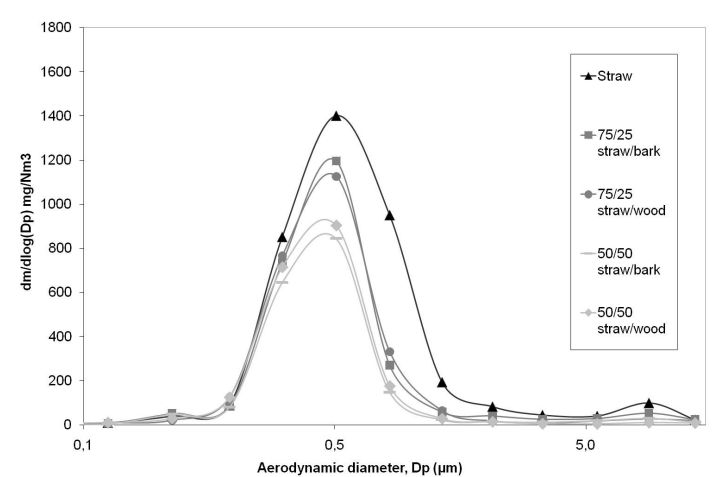

Figure 2. Flue gas particle mass size distribution.

The flue gas particle mass size distribution can be seen in Figure 2, and as can be seen, the particles were in all cases dominated by fine particles with a mass median diameter between 0.19 and 0.82 $\mu \mathrm{m}$. A significant reduction of the fine particles were shown in the co-combustion experiments and at $25 \%$ and $50 \%$ woody biomass share, the fine mode peak value at $0.39 \mu \mathrm{m}$ drops to about $80-85$ and $60-65 \%$ of the value for straw. The coarse particles, with a mass diameter between 5.5-13.4, $\mu \mathrm{m}$ do also decrease as the share of woody biomass increases and comparing data for straw/wood and straw/bark gives that the former has a lower mass concentration in the coarse mode, ranging between $10-25 \%$ of the values for pure straw. The corresponding values for straw/bark mixes are between $30-50 \%$ of those found for pure straw.

The results from the SEM/EDS analysis showed that the fine particles were dominated by $\mathrm{K}, \mathrm{Cl}$ and $\mathrm{S}$ with similar levels for all fuel mixes. Results from the XRD analysis 


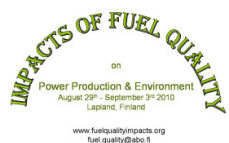

showed that the fine particles contained $\mathrm{KCl}, \mathrm{K}_{2} \mathrm{SO}_{4}$ and $\mathrm{K}_{3} \mathrm{Na}\left(\mathrm{SO}_{4}\right)_{2}$, see table 5. The composition of the coarse particles is more scattered although rich in $\mathrm{K}$ and $\mathrm{Si}$ as well as $\mathrm{Ca}, \mathrm{S}$ and $\mathrm{Cl}$. A similar (and scattered) elemental distribution was also found on the lee side of the air-cooled deposit sampling probes, see Figure 5).

The fraction of $\mathrm{K}$ that was volatilized during combustion and found as fine particle matter in the flue gases was estimated by the ratio of the amount of $\mathrm{K}$ found in fine PM to the total amount of $\mathrm{K}$ of in-going fuel. The amount of $\mathrm{K}$ found in the fine $\mathrm{PM}\left(\mathrm{PM}_{1}\right)$ was estimated by SEM-EDS analyses on stages 0.06-0.19 and 0.5-1.34 $\mu \mathrm{m}$ (i.e. the fine mode) in the impactor. Based on these estimations $80 \%$ of the fuel $\mathrm{K}$ for pure straw was found in the fine particle mode, with slightly lower values for the fuel mixes from straw/wood and straw/bark. These results therefore shows that the main part of the potassium will be released to the gas phase during the thermal conversion of the fuel particle even if the fuel particle is rich in reactive silicon as in the case with the wheat straw.

Previous research has showed that both the combustion temperature and heating rate as well as the ash composition have a significant effect on the release of chlorine, sulfur and potassium to the gas phase $[11,12]$. Especially the inherent amounts of silicon and chlorine have a large impact on the balance between potassium release and potassium retention to the residual ash. The findings on $\mathrm{K}$ release in this work is in the upper range of $\mathrm{K}$ release data at high temperatures from previous experimental work by Knudsen on pure wheat straw [12], van Lith on pure bark [13], and Gilbe on several (Si rich) different biomasses [14], all authors using equipment more similar to grate firing conditions than powder combustion conditions. Compared to the modelling results in section 3.1 , the experimental data shows a much higher $\mathrm{K}$ release to the gas phase. We interpret the high $\mathrm{K}$ release rates found in this work as consequence of (i) high heating rates $\left({ }^{\circ} \mathrm{C} / \mathrm{s}\right.$ ), (ii) high fuel particle process temperature and (iii) limited mixing between the different fuel particles in the flame/furnace which all combine to a reduced availability of $\mathrm{K}$ to react with Si during the devolatilization and char burnout phase of the fuel particle. Thus, the prevailing conditions during both the thermal conversion of the fuel particle and in the furnace are far from global equilibrium.

\subsection{Bottom ash, slag and fly ash formation}

The bottom ash for pure straw was made up of $100 \%$ slag consisting of totally sintered ash, i.e., the deposited ash was completely fused to larger blocks and was given a category 4 sintering degree according to the classification scheme described in section 2.3. The addition of wood and bark both decreased the amount of bottom ash as well as the sintering degree classification to category 3 for straw/wood 75/25 and category 2 for the other fuel mixes. A distinct difference in the visual appearance of the bottom ash was clear when both kinds of woody biomass were used, and a bottom ash that was more porous and less sintered was observed. The results from the SEM/EDS analysis of the different bottom ashes show a significant increase in $\mathrm{Ca}$ and a significant decrease in $\mathrm{Si}$ when straw were co-combusted with the woody biomass fuels, see Figure 3.

The amorphous contribution in the bottom ash was high for all fuel mixes according to the XRD analyses, Table 4, but the results indicate a small increase of the crystalline share as more wood and especially bark was used as co-firing fuel. Out of the present crystalline phases found from the XRD analysis, it can be seen that the straw bottom ash 


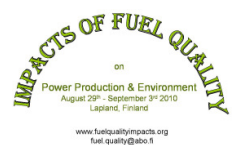

is relatively rich in $\mathrm{KAlSi}_{2} \mathrm{O}_{6}$ whereas the straw/wood mixes display $\mathrm{CaO} / \mathrm{CaCO}_{3}, \mathrm{MgO}$ and $\mathrm{SiO}_{2}$ (quarts and cristobalite) that sum up to between $36-61$ wt- $\%$ of the crystalline material.

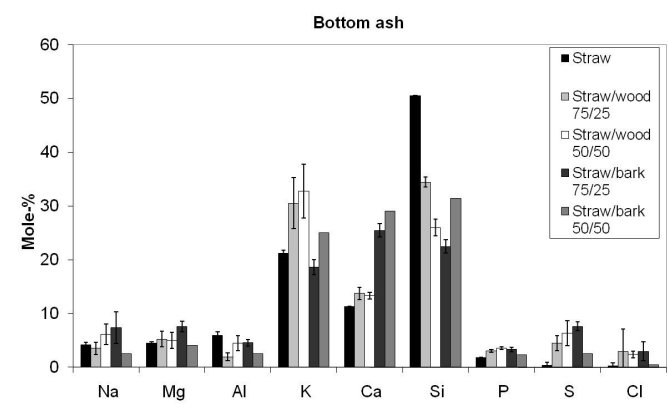

Figure 3. Elemental composition (on a $\mathrm{C}$ - and $O$ free basis) of bottom ash.
The former phase $\left(\mathrm{KAlSi}_{2} \mathrm{O}_{6}\right)$ is most probably a reaction product between the alkali rich melt and mullite (ceramic lining). The straw/wood 75/25 and straw/bark 75/25 also have minor levels of $\mathrm{Ca}_{5}\left(\mathrm{PO}_{4}\right)_{3}(\mathrm{OH})$ and $\mathrm{Ca}_{3} \mathrm{Mg}\left(\mathrm{SiO}_{4}\right)_{2}$. Straw/wood 75/25 also contain rather high amounts of $\mathrm{KCl}$, which was somewhat unexpected. The additional $\mathrm{Ca}$ from the bark was mainly present as an additional surplus of $\mathrm{CaO} / \mathrm{CaCO}_{3}$ as well as two K-Ca-carbonates, the latter only in the straw/bark $75 / 25$. Phases in common in the experimental data and the equilibrium calculation is solid $\mathrm{K}_{2} \mathrm{SO}_{4}$ and $\mathrm{Ca}_{5}\left(\mathrm{PO}_{4}\right)_{3}(\mathrm{OH})$, i.e. phases such as $\mathrm{CaO}, \mathrm{MgO}$ and $\mathrm{K}-\mathrm{Ca}-\mathrm{CO} 3$ found in different ash fractions are not thermodynamically stable according to the modelling calculations.

Table 4. Identified crystalline phases in various ash-, deposit- and particle fractions.

$\mathrm{BA}=$ bottom ash, DW/L $250 / 550=$ deposit probe at $250 / 550^{\circ} \mathrm{C}$ wind/lee side*, $\mathrm{FA}=$ fly ash,

$\mathrm{FM}=$ fine particulate matter/impactor. *At least one present, significant phase could not be identified,

\# Predominantly amorphous material, \#\# Significant amount of amorphous material, Cristobalite

\begin{tabular}{|c|c|c|c|c|c|c|c|c|c|c|c|c|c|c|c|c|c|c|c|c|c|c|c|c|c|c|c|c|c|c|c|c|}
\hline \multirow[t]{3}{*}{ Phase } & \multicolumn{6}{|c|}{ Straw100 } & \multicolumn{7}{|c|}{ Straw/Wood $75 / 25$} & \multicolumn{5}{|c|}{ Straw/Wood $50 / 50$} & \multicolumn{7}{|c|}{ Straw/Bark 75/25 } & \multicolumn{7}{|c|}{ Straw/Bark 50/50 } \\
\hline & BA & FA & DW & DW & DL & FM & $\mathrm{BA}$ & FA & DW & DL & \begin{tabular}{|l|l} 
DW & 1 \\
\end{tabular} & \begin{tabular}{|l|l}
$\mathrm{DL}$ & 1
\end{tabular} & FM & BA & FA & DW & DW 1 & DL & BA & FA & DW & \begin{tabular}{|l|l}
$\mathrm{DL}$ & $\mathrm{I}$ \\
\end{tabular} & DW & DL & FM & BA & FA & DW & DL & DW & $\mathrm{DL}$ & FM \\
\hline & & & 550 & 250 & 250 & & & & 550 & 550 & 2502 & \begin{tabular}{|l|}
250 \\
\end{tabular} & & & & 550 & 2502 & 250 & & & 550 & 550 & 250 & 250 & & & & 550 & 550 & 250 & 250 & \\
\hline & $\#$ & \#\# & \#\# & & & & \# & \#\# & \#\# & \#\# & \#\# & & & \# & & \#\# & & & \#\# & $\#$ & \#\# & \#\# & & & & \# & \#\# & \#\# & \#\# & & & \\
\hline $\mathrm{SiO}_{2}$ & 4 & 12 & 11 & 8 & & & 12 & 11 & 10 & & 12 & 2 & & & 6 & 13 & 7 & & 16 & 8 & 13 & & 8 & & & 7 & 7 & 17 & & 10 & 4 & \\
\hline$(\mathrm{Na} / \mathrm{K})$ & & & & & & & & & 11 & & & & & & & 10 & & & 6 & 3 & 15 & & & & & 13 & & 9 & & & & \\
\hline $\mathrm{CaO}$ & & & & & & & 4 & 3 & 1 & & 2 & & & 24 & 5 & & & & 22 & 14 & 2 & & 11 & & & 42 & 16 & 3 & & 17 & 8 & \\
\hline $\mathrm{MgO}$ & & & & & & & 10 & 4 & 1 & & 3 & & & 4 & 4 & & & & 6 & 4 & & & 3 & & & 8 & 4 & 5 & & 3 & & \\
\hline $\mathrm{Ca}(\mathrm{OH}$ & & & & & & & & & & & & & & & & & & & 2 & & & & & & & & & & & & & \\
\hline $\mathrm{CaCO}_{3}$ & & 3 & & & & & & & & & & & & 4 & 4 & & & & 18 & 5 & & & & & & & 2 & & & 1 & & \\
\hline $\mathrm{CaK}_{2} \mathrm{CO}$ & & & & & & & & & & & & & & 18 & & & & & & & & & & & & & & & & & & \\
\hline $\mathrm{Ca}_{2} \mathrm{~K}_{2}$ & & & & & & & & & & & & & & 7 & & & & & & & & & & & & & & & & & & \\
\hline $\mathrm{CaSC}$ & & & & & & & & & & & & & & & & & & & & & 7 & & & & & & & & & 4 & & \\
\hline $\mathrm{K}_{2} \mathrm{SO}_{4}$ & & 9 & 50 & 10 & 6 & 13 & 7 & 11 & \begin{tabular}{|l|l}
34 \\
\end{tabular} & 22 & 6 & \begin{tabular}{l|l}
9 & \\
\end{tabular} & 14 & & 10 & 5 & 11 & 20 & 6 & 5 & 11 & 13 & 4 & \begin{tabular}{|l|}
11 \\
\end{tabular} & 16 & 7 & 4 & 7 & 12 & 2 & 11 & 20 \\
\hline $\mathrm{K}_{3} \mathrm{Na}\left(\mathrm{SO}_{4}\right)_{2}$ & & 4 & 1 & 8 & 9 & 9 & 8 & 6 & & & 4 & 6 & 7 & & 4 & & 7 & 8 & 1 & & & 3 & 6 & 10 & 10 & & 7 & & & & & 11 \\
\hline $\mathrm{KCl}$ & & 57 & 8 & 68 & 85 & 78 & 25 & 46 & & 57 & \begin{tabular}{|l|l|}
59 \\
\end{tabular} & \begin{tabular}{l|l}
78 \\
\end{tabular} & 78 & & 40 & 2 & 60 & 72 & & 36 & 1 & 78 & 53 & \begin{tabular}{|l|l|}
79 \\
\end{tabular} & 75 & & 41 & 4 & 88 & 44 & 73 & 69 \\
\hline $\mathrm{Ca}_{5}\left(\mathrm{PO}_{4}\right)_{3}(\mathrm{OH})$ & & 6 & & & & & 11 & 8 & 6 & & 5 & 4 & & & 8 & 16 & 7 & & 9 & 13 & 9 & 2 & 7 & & & 7 & 6 & 20 & & 7 & & \\
\hline $\mathrm{KAlSi}_{2} \mathrm{O}$ & \begin{tabular}{|l|l}
96 \\
\end{tabular} & & & & & & & & & & & & & 15 & & & & & 3 & & & & & & & & & & & & & \\
\hline $\mathrm{CaMg}$ & & & & & & & & & & & & & & & & & & & & & & & & & & & & 12 & & & & \\
\hline $\mathrm{Ca}_{3} \mathrm{Mg}\left(\mathrm{SiO}_{4}\right)_{2}$ & & 9 & 10 & 6 & & & 8 & 12 & 8 & & 9 & & & & 17 & 19 & 8 & & 8 & 12 & 13 & 3 & 9 & & & & 13 & 10 & & 12 & 5 & \\
\hline $\mathrm{SiO}_{2}$ & & & 19 & & & & 10 & & 29 & & & & & 29 & & 35 & & & 2 & & 28 & & & & & 2 & & 12 & & 2 & & \\
\hline $\mathrm{Fe}_{2} \mathrm{O}_{3}$ & & & & & & & 4 & & & 20 & & & & & & & & & & & & & & & & & & & & & & \\
\hline Sum & 100 & 100 & \begin{tabular}{|l}
99 \\
\end{tabular} & 100 & 100 & 100 & 99 & 101 & \begin{tabular}{|l|l|}
100 & \\
\end{tabular} & \begin{tabular}{|l|l|}
99 \\
\end{tabular} & $100 \mathrm{~s}$ & \begin{tabular}{l|l}
99 & \\
\end{tabular} & 99 & 101 & 99 & 100 & 100 & 100 & 99 & 100 & 99 & 99 & 101 & 100 & 101 & \begin{tabular}{|l|}
99 \\
\end{tabular} & 100 & \begin{tabular}{|l|}
99 \\
\end{tabular} & 100 & 102 & 101 & 100 \\
\hline
\end{tabular}

*Analysis on straw 100-DL and straw/wood-FM is not available

A fraction of the residual ash, i.e. the ash that is left after a full conversion of the fuel particle, ends up in the bottom ash and once caught in the bottom ash deposit the availability of interaction between the straw and woody biomass particles are reduced unless a liquid phase is present that can (partially) dissolve the fuel ash elements. The presence of $\mathrm{CaO} / \mathrm{CaCO}_{3}$ also indicates that a fractionation of the fuel has taken place, creating small $\mathrm{CaO}$ grains that deposit in the bottom ash. As we see it, a pre-requisite to the reduced slagging propensity is that wood ash ( $\mathrm{Ca}$ rich) particles need to deposit directly in the (straw based) K-silicate melt, otherwise no positive interaction will occur. 


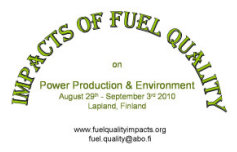

In addition, we interpret the presence of the K-Ca-carbonates mainly as a result of individual wood/bark particles ending up in the bottom ash without further interaction with the straw ash. Based on these results, the decrease in slagging/sintering propensity of the co-firing mixes can be explained by (i) diluting of the straw ash and (ii) a change in the elemental composition of the resulting bottom ash, i.e. decrease in $\mathrm{K}$ and $\mathrm{Si}$ and increase of $\mathrm{Ca}$ providing for the formation of $\mathrm{Ca}$ based phases such as $\mathrm{CaO} / \mathrm{CaCO}_{3}$. In terms of $\mathrm{Ca}$, the latter findings agree with the work done by Öhman et al. [8] who showed that the addition of $\mathrm{CaCO}_{3}$ to problematic woody biomass decreased slag formation of pellets when used in residential pellet burners.

The SEM/EDS analysis of fly ash show that it in general resembles the fuel ash composition, although a slight depletion of $\mathrm{K}$ in pure straw and an enrichment in $\mathrm{K}$ can be seen in the two straw/wood fuel mixes. The most dominant trends in individual elements when the co-firing share of woody biomass increase are found in $\mathrm{K}$, which increase for straw/wood and decrease for straw/bark, as well as $\mathrm{Ca}$ and $\mathrm{Si}$ which are increased and decreased respectively.

\subsection{Deposit formation}

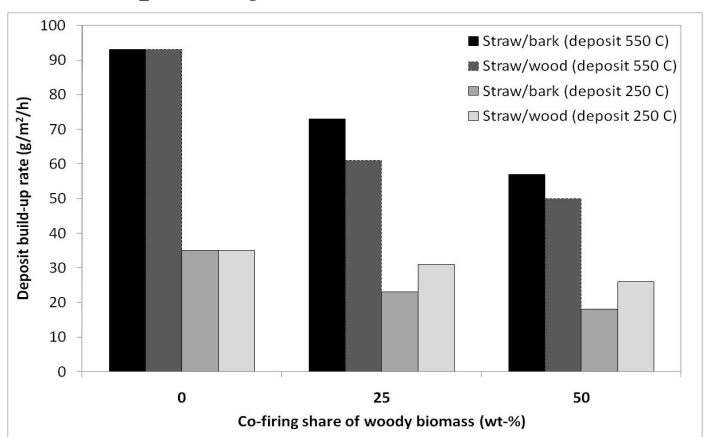

Figure 4. Deposit build-up rate at 250 and $550^{\circ} \mathrm{C}$.
The deposit build-up rates (DBU) of the probes are shown in Figure 4. For both probe surface temperatures, the build-up rate was highest for pure straw at levels of the $90 \mathrm{~g} \cdot \mathrm{m}^{-2} \mathrm{~h}^{-1}\left(550^{\circ} \mathrm{C}\right)$ and $35 \mathrm{~g} \cdot \mathrm{m}^{-2} \mathrm{~h}^{-1}$ $\left(250^{\circ} \mathrm{C}\right)$, and a decrease in deposit formation was observed as wood and bark was co-fired with straw to levels close to $50 \mathrm{~g} \cdot \mathrm{m}^{-2} \mathrm{~h}^{-1}\left(550^{\circ} \mathrm{C}\right)$ for the straw/wood $50 / 50 \mathrm{mix}$ and as $18 \mathrm{~g} \cdot \mathrm{m}^{-2} \mathrm{~h}^{-1}\left(250^{\circ} \mathrm{C}\right)$ for the straw/bark 50/50 mix. At similar co-

firing rates of both wood and bark, the observed differences in DBU are relatively small, although some differences can be seen. For both straw/wood and straw/bark, the deposits became more porous in comparison to that for pure straw. The deposition rates at the $550^{\circ} \mathrm{C}$ probe surface temperature show a good correlation to fuel potassium content $(\mathrm{mg} / \mathrm{kg})$. In the case of the straw/wood mixes, the ash content shows a similar (strong) correlation to DBU, but this trend was not observed for the straw/bark mixes. The latter trend, although based on two fuel mixes, is opposite to findings of Capablo et al. [15] who showed that DBU was correlated to ash content and that all fuels with an ash content above $3.5 \mathrm{wt}-\%$ resulted in deposit rates above $100 \mathrm{~g} \cdot \mathrm{m}^{-2} \mathrm{~h}^{-1}$. The DBU $\left(550^{\circ} \mathrm{C}\right)$ in this work are in the lower ranges compared to deposition data from other work on combustion of pulverised biomass in laboratory scale [15, 6]. Skrifvars et al. [10] reports that during (pf) combustion of wood, with ash content between 0.4-0.7 wt- $\%$, in a $80 \mathrm{MW}_{\text {th }}$ boiler, the DBU were between $15-75 \mathrm{~g} \cdot \mathrm{m}^{-2} \mathrm{~h}^{-1}$.

The DBU observed at the $250^{\circ} \mathrm{C}$ probe surface do not show a clear correlation to the fuel composition analysis. However, the trends in deposition rate show a weak correlation to the $\mathrm{KCl}$ concentration in the actual deposits. The wind side deposit chemistry, Figure 5 , resemble the fuel ash composition, indicating that the main deposit mechanism is direct impaction of ash particles on the probe surface. 


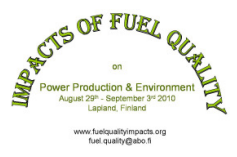

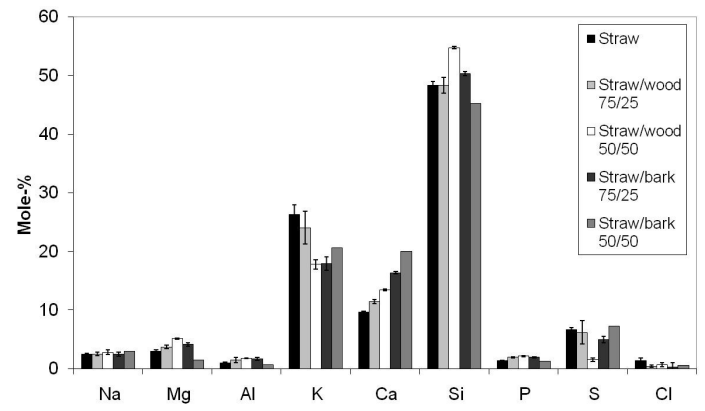

(a) $550^{\circ} \mathrm{C}$ deposit probe - wind side

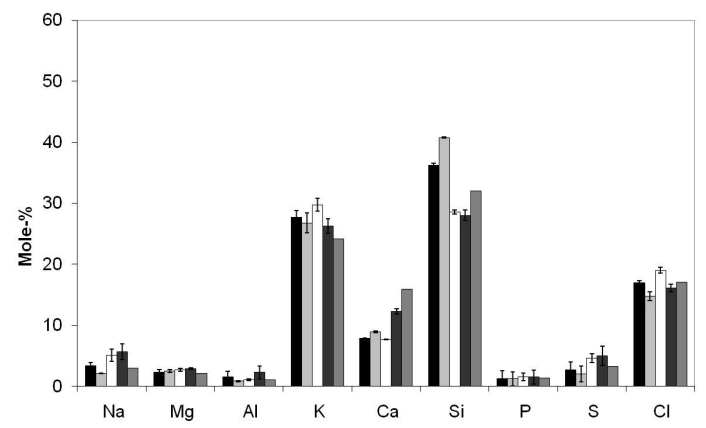

(c) $250^{\circ} \mathrm{C}$ deposit probe - wind side

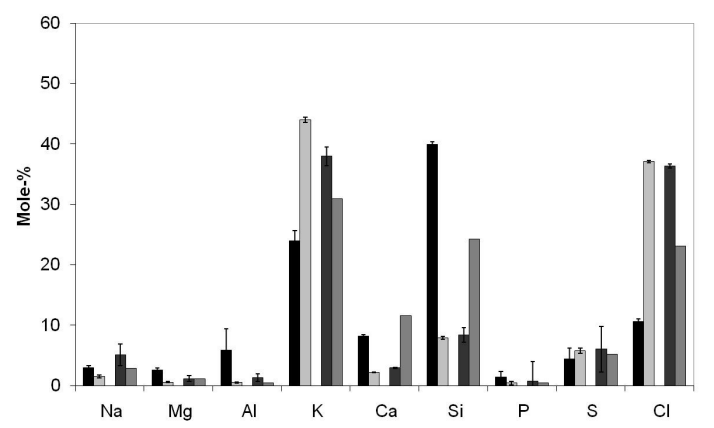

(b) $550^{\circ} \mathrm{C}$ deposit probe - lee $\operatorname{side}^{1}$

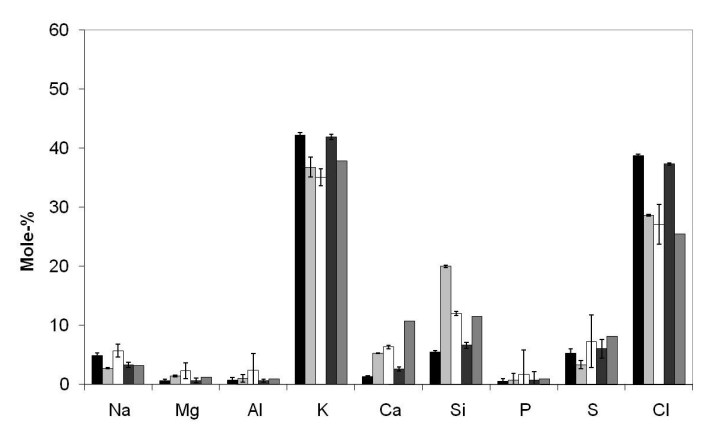

(d) $250^{\circ} \mathrm{C}$ deposit probe - lee side

Figure 5. Elemental composition (on a $\mathrm{C}$ - and $\mathrm{O}$ free basis) of deposits collected at the surface of the $250^{\circ} \mathrm{C}$ and $550^{\circ} \mathrm{C}$ deposit probes from co-firing of straw and woody biomass.

Lee side deposits display large variations in elemental composition with higher shares of $\mathrm{K}, \mathrm{Cl}$ and $\mathrm{Si}$. Comparing the trends in elemental composition to the XRD data, keeping in mind the significant contribution of amorphous material, it is clear that (i) $\mathrm{K}$ and $\mathrm{Cl}$ is mainly present as $\mathrm{KCl}$ and (ii) the additional $\mathrm{Ca}$ from the woody biomass, especially the bark fuel, provided $\mathrm{CaO}$ particles that did deposit on/reacted on the cooled probes. This indicates that the deposit rate decrease for the straw/wood and straw/bark mixes, at the $550^{\circ} \mathrm{C}$ probe, is mainly an effect of dilution of the straw ash, and in the case of straw/bark also to some extent an effect of interaction between the fuel ash $(\mathrm{Ca})$ components. The $\mathrm{S} / \mathrm{Cl}$ ratio, display a small increase as more woody biomass is used, but it seems unlikely that any positive effects on deposit formation, can be seen in this case.

The $\mathrm{SiO}_{2}$ found in the XRD analysis is present as both quarts and cristobalite. Cristobalite, which is a high temperature phase of ordinary quarts, has high affinity to alkali at elevated temperatures, and because of this, it seems likely that during its passage through the furnace, it should have reacted with (gaseous) alkali if residence times were long and proper mixing was the case. The molar ratio of $\mathrm{Si}$ to $(\mathrm{K}+\mathrm{Mg}+\mathrm{Ca})$, decrease as more woody biomass is co-fired with straw. For the straw/bark 75/25 mix the abovementioned ratio is far below 1 , and thus, in the ideal case, all $\mathrm{Si}$ could react with $\mathrm{K}, \mathrm{Ca}$ and $\mathrm{Mg}$ to form condensed phases such as $\mathrm{K}-, \mathrm{Ca}$, and $\mathrm{Ca}-\mathrm{Mg}$-silicates. According to equilibrium calculations $40-60$ mole- $\%$ of all $\mathrm{Si}$ is present as slag and no cristobalite

\footnotetext{
${ }^{1}$ Analysis of the lee side of the $550^{\circ} \mathrm{C}$ deposit probe for straw/wood 50/50 is not available.
} 


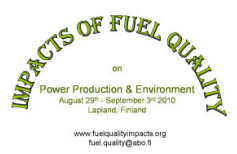

should be expected. Thus, these are all strong indications that the prevailing condition in the specific pilot scale furnace used in this work was far from equilibrium.

\subsection{General discussion based on all findings in this work}

The principle of powder combustion involves high temperature and short residence time during the thermal conversion of the individual fuel particle. In order to obtain complete conversion of the fuel it has to be comminuted. This implies that the bed environments typical for grates and fluidized beds that provides good opportunities for contact between gaseous and solid initial formed ash matter, not are present. In grate and fluidized bed environment the density of the ash forming compounds are considerable higher and together with a longer residence time surroundings is created where the ash transformation reactions could approach equilibrium. In the flame of a powder burner the fuel are dispersed. This implies that the already limited mutual ash interaction and encounters due to the small fuel particles will be even more limited due to the extensive fuel dispersion. In such combustion environment fast reactions involving gaseous ash compounds are favored at the expense of reactions where condensed components participate. Accordingly, the conditions promote gas phase reactions resulting in the formation of chlorides, sulfate and carbonates whereas reactions involving condensed reactants are suppressed. However, reaction between condensed and gaseous components as for instance between $\mathrm{KOH}(\mathrm{g})$ or $\mathrm{KCl}(\mathrm{g})$ and $\mathrm{SiO}_{2}(\mathrm{~s})$ will occur, since silica particles will encounter a flue gas containing gaseous potassium (although diluted) and molten Ksilicates will form. The frequently observed positive influence of $\mathrm{CaO}$ on low melting $\mathrm{K}$ silicates in fluidized bed and in grate combustion will probably not occur in the flame and flue gas of powder combustion. If these condensed components are settled on the bottom of the boiler/furnace/burner walls, conditions for obtaining equilibrium are more favorable and reactions will take place. In general it can be concluded that under powder combustion conditions equilibrium are approached selectively and that the ash matter are strongly fractionated. The general results in this paper are useful for straw-fired power stations looking for alternative co-firing fuels.

\section{CONCLUSIONS}

General ash transformation processes during co-firing of straw and woody biomass have been studied in $150 \mathrm{~kW}$ pulverised fuel-fired burner, and the work has led to the following conclusions:

- The results show that fast reactions involving gaseous ash compounds are favored at the expense of reactions where condensed components participate. Accordingly, the conditions promote gas phase reactions resulting in the formation of chlorides, sulfate and carbonates whereas reactions involving condensed reactants are suppressed.

- The slagging propensity of the co-firing mixes was reduced compared to that for pure straw, and this is interpreted as an effect of (i) dilution of the ash forming elements of the straw and (ii) a change in the elemental composition of the resulting bottom ash, mainly due to direct deposition of (Ca rich) particles in the (straw based) K-silicate melt thus providing for the formation of more high temperature melting silicates and oxides. 


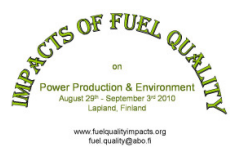

- Deposition rates: the reduced fouling propensity for (i) straw/wood is mainly due to dilution of the straw ash and (ii) the deposit rate decrease for straw/bark is an effect of both dilution and to some extent interaction between fuel ash components.

- In general it can be concluded that under powder combustion conditions equilibrium are approached selectively and that the ash matter are strongly fractionated.

\section{ACKNOWLEDGEMENTS}

This work was funded by Värmeforsk (Swedish Thermal Engineering Research Institute), Vattenfall AB Group Function R\&D (Sweden), Vattenfall A/S (Denmark) and the national (Swedish) strategic research program Bio4Energy.

\section{REFERENCES}

1. L.L. Baxter, et al., The behavior of inorganic material in biomass-fired power boilers: field and laboratory experiences, Fuel Processing Technology, 54(1998), 47-78

2. J.F. Frandsen, Utilizing biomass and waste for power production--a decade of contributing to the understanding, interpretation and analysis of deposits and corrosion products, Fuel, 84(2005), 1277-1294

3. T.R. Miles, et al., Boiler deposits from firing biomass fuels, Biomass and bioenergy, 10(1996), 125-138

4. D.C. Dayton, Effect of Coal Minerals on Chlorine and Alkali Metals Released during Biomass/Coal Cofiring, Energy \& Fuels, 13(1999), 8

5. K. Wieck-Hansen, P. Overgaard, and O.H. Larsen, Cofiring coal and straw in a $150 \mathrm{MWe}$ power boiler experiences, Biomass and bioenergy, 19(2000), 395-409

6. M. Theis, et al., Fouling tendency of ash resulting from burning mixtures of biofuels. Part 2: Deposit chemistry Fuel, 85(2006), 1992-2001

7. L. Tobiasen, et al., Deposit characteristic after injection of additives to a Danish strawfired suspension boiler, Fuel Processing Technology, 88(2007), 1108-1117

8. M. Öhman, et al., Effect of Kaolin and Limestone Addition on Slag Formation during Combustion of Wood Fuels, Energy \& Fuels, 18(2004), 1370-1376

9. M. Berg, S. Thaaning Pedersen, and G. Rohde, Experience from straw dust firing in Amager unit 2, VGB PowerTech, 5(2007)

10. B.-J. Skrifvars, et al., Ash behaviour in a pulverized wood fired boiler--a case study, Fuel, 83(2004), 1371-1379

11. P.A. Jensen, et al., Experimental Investigation of the Transformation and Release to Gas Phase of Potassium and Chlorine during Straw Pyrolysis, Energy \& Fuels, 14(2000), $1280-1285$

12. J.N. Knudsen, P.A. Jensen, and K. Dam-Johansen, Transformation and Release to the Gas Phase of $\mathrm{Cl}, \mathrm{K}$, and S during Combustion of Annual Biomass, Energy \& Fuels, 18(2004), 1385-1399

13. S.C. van Lith, et al., Release to the Gas Phase of Inorganic Elements during Wood Combustion. Part 2: Influence of Fuel Composition, Energy \& Fuels, 22(2008), 15981609

14. C. Gilbe, et al., Slagging Characteristics during Residential Combustion of Biomass Pellets, Energy \& Fuels, 22(2008), 3536-3543

15. J. Capablo, et al., Ash Properties of Alternative Biomass, Energy \& Fuels, 23(2009), 1965-1976 